\title{
The Quality of Life in Hypertention Patients' Before and After E-Discharge Planning Intervention
}

\author{
$* 1^{\text {st }}$ Fitri Arofiati \\ School of Nursing \\ Universitas Muhammadiyah \\ Yogyakarta \\ Yogyakarta, Indonesia \\ fitri.arofiati@umy.ac.id
}

\author{
$2^{\text {nd }}$ Fitri Ramadhani \\ School of Nursing \\ Universitas Muhammadiyah \\ Yogyakarta \\ Yogyakarta, Indonesia
}

\begin{abstract}
Hypertension can cause a decrease in physical health, psychological, social relationships, complications, and inadequate treatment that will impact in decreased quality of life. Therefore, the nurse's role is to help improve patient health through the provision of discharge planning. The discharge planning has been developed into e-discharge planning which aims to facilitate and maintain information received by patients to be implemented at home. However, there are no studies that examine the effect on quality of life patients' using e-discharge planning. This study aims to know the comparison of the quality of life of patients with hypertension before and after the e-discharge planning intervention. This study was Pre-experimental design using a pre-posttest without a control group. Data was collected by using a questionnaire which was carried out twice, the first questionnaire was given when the patient was hospitalized and the second questionnaire was given when the patient was controlled at the polyclinic of PKU Gamping Hospital. Respondents in this study were 50 people who were determined by total sampling techniques. The results showed an increase in the quality of life of patients with hypertension before and after the administration of e-discharge planning, proved by the statistic test using paired t-test with a P-value of 0,000 (p $<0.05)$. E-discharge planning is useful to improve the quality of life of patients with hypertension
\end{abstract} Life

Keywords-Hypertension, E-Discharge Planning, Quality of

\section{INTRODUCTION}

The World Health Organization (WHO) in 2019 described that hypertension is characterized by blood pressure readings that exceed of 140 (systolic pressure) and 90 (diastolic pressure) with repeated measurements at rest (Hospital, 2016). Hypertension is the cause of death of 7.5 million people in the world or $12.8 \%$ of all deaths and the uncontrolled hypertension increased from 600 million in 1980 to nearly 1 billion in 2008 [1]. It is also stated that Hypertension is one of non-communicable diseases caused by unhealthy lifestyles, including smoking, consumption of alcoholic beverages, lack of physical activity, and lack of consumption of fruits and vegetables.

The prevalence of hypertension in 2018 in Indonesia has increased from $25.8 \%$ to $34.1 \%$ proved that hypertension is one of the types of non-communicable diseases that occupy the third highest in Indonesia, especially in the Special
Region of Yogyakarta where in 2007 with a prevalence of $35.0 \%$, in 2013 ranked fifth as a province with hypertension cases with a prevalence of $35.8 \%$, and in 2018 with a prevalence of $34.0 \%$ [2].

Uncontrolled hypertension that lasts for a long time can cause many complications which are the main cause of chronic kidney failure. This can cause discomfort and result in decreased quality of life of people with hypertension [3].showed that the quality of life of hypertensive patients is lower than individuals who do not suffer from hypertension, and the declining quality of life of a person can create certain barriers such as decreased physical, psychological health, social relationships, hypertension complications, inadequate care and inappropriate treatment of hypertension can result in a decrease in the quality of human life [4].

Afiani (2019) reported that there are several factors that affect the quality of life of patients with hypertension, including adherence to therapy, economic level, and type of hypertension [5]. It was revealed that the higher the level of therapy adherence, economic level, and type of hypertension, the better the quality of life of patients. Nurses play a role in improving the quality of life of patients with hypertension, as one of the nurses' roles as educators. The role of the nurse as an educator can help improve patient health through the provision of knowledge related to nursing and medical measures received by patients. The role of nurses as educators is also carried out by nurses ranging from patients being treated to patients returning with the provision of discharge planning [6].

Discharge planning is a patient discharge record written by the nurse on the patient notes sheet to maximize the patient's potential to live independently [7]. With the provision of discharge planning that is not good it will be one of the factors that influence the duration of the patient's healing time, effective discharge planning must include some follow-up assessments to get comprehensive information such as changes in patient needs, nursing diagnoses, and accessible health services [7].

\section{METHOD}

This study was a pre-experimental design research design using pre-posttest without control group. The number of respondents in this study were 50 people, who have criteria's: has a primary diagnosis of hypertension, were 
hospitalized for and exercised control at PKU Muhammadiyah Gamping Hospital, had smartphones (can be patient or family). This research was conducted at PKU Muhammadiyah Gamping Hospital in October 2019 to February 2020. This study used e-discharging planning in the home care record as an electronic document of the respondents, while to measure the quality of life was using Short-Form 36

\section{RESULT}

\section{A. Characteristic of respondents}

All of patients who suffering hypertension after hospitalized and meet the health care provider at out-patient department were included in this study as well as 50 people. Table 1 showed the characteristic of respondents regarding to the age and gender.

TABLE I. CHARACTERISTICS OF RESPONDENTS

\begin{tabular}{|l|c|c|}
\hline $\begin{array}{c}\text { Characteristics } \\
\text { of respondents }\end{array}$ & $\begin{array}{c}\text { Frequency } \\
\text { (f) }\end{array}$ & $\begin{array}{c}\text { Percentage } \\
(\%)\end{array}$ \\
\hline Age & 20 & 40,0 \\
$<60$ y/o & 23 & 46,7 \\
$60-70$ y/o & 7 & 13,3 \\
$>70$ y/o & 10 & 20 \\
\hline Gender & 40 & 80 \\
Male & \\
Female & \multicolumn{2}{|}{} \\
\hline
\end{tabular}

The table showed that patients suffering from hypertension and hospitalization at PKU Muhammadiyah Gamping Hospital are mostly at the age of 60-70 years with a total of 23 people $(46.7 \%)$ and mostly are women $(80.0 \%)$.

\section{B. Quality of life}

\section{1) Dimensions of Physical Health}

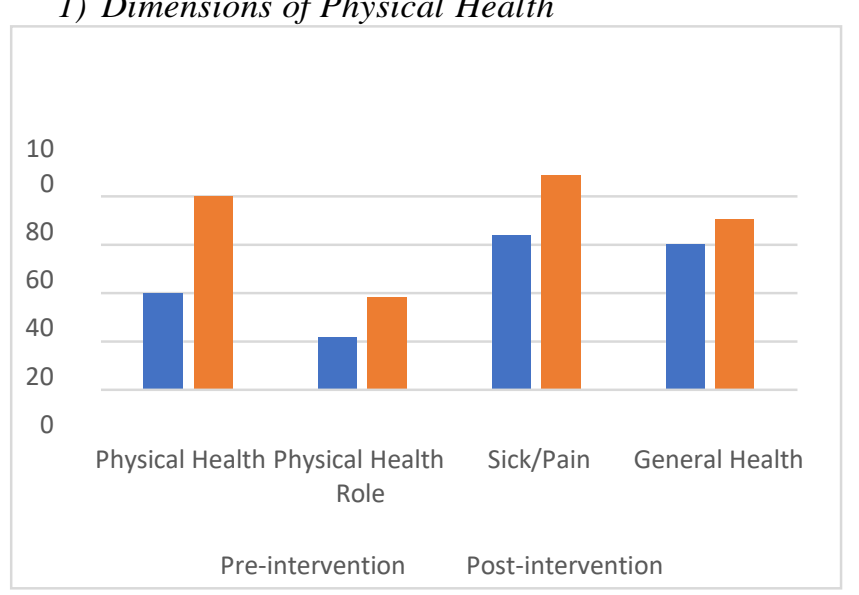

Fig. 1. Dimension of Physical Health

The diagram above described that there are significant differences before and after the intervention in all domains studied, and proved that there are differences in the quality of life of hypertensive patients before and after giving edischarge planning. Thus, it can be seen that patients experience an increase in physical health by $40.33 \%$, as well as the role of physical health has increased by $16.66 \%$, in pain / pain improved by $24.93 \%$, general health increased by $10.4 \%$.

\section{2) Emotional problems (mental health)}

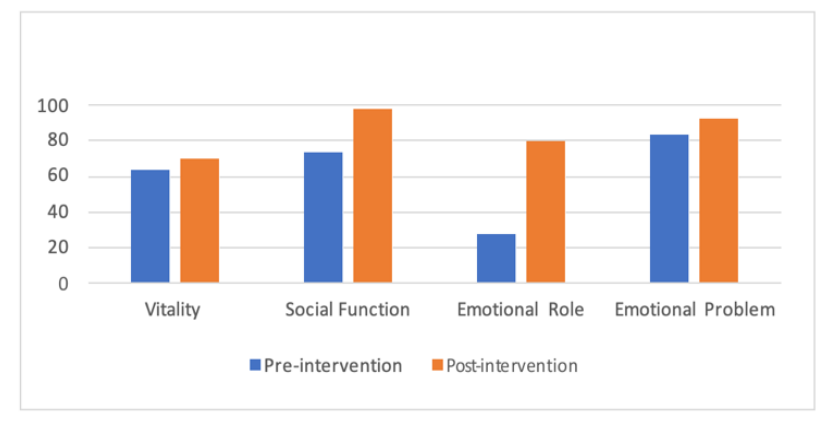

Fig. 2. Dimension of Emotional

The diagram 2 described about the increase in each domain, vitality increased by $5.74 \%$ social function increased by $24.17 \%$, emotional role increased by $53.33 \%$, and emotional problems increased by $8.8 \%$.

\section{3) Quality of life}

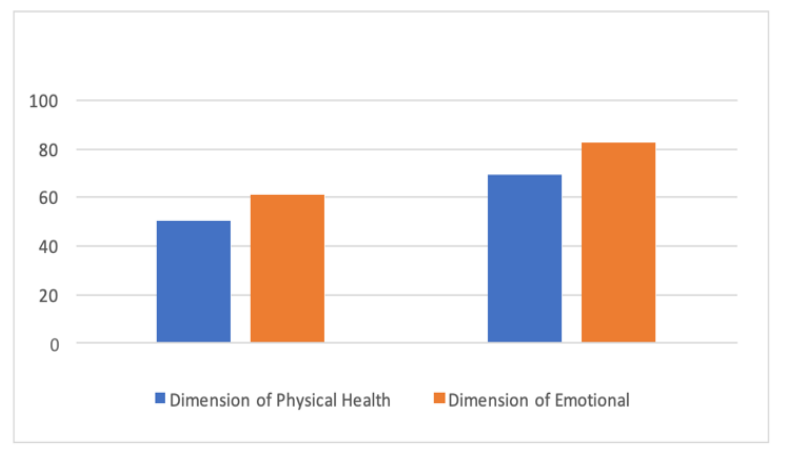

Fig. 3. Quality of Life

The diagram showed an increase in the percentage in both dimensions, the physical health dimension increased by $19 \%$ and the emotional or mental health dimension increased by $21 \%$. These results indicate that there are differences in the quality of life of hypertensive patients before and after the administration of e-discharge planning in the 2 dimensions of the SF-36 questionnaire.

\section{4) Statistical analysis}

TABLE II. THE DIFFERENCE BETWEEN PRE-POSTTEST INTERVENTION OF E-DISCHARGE PLANNING TO THE QUALITY OF LIFE

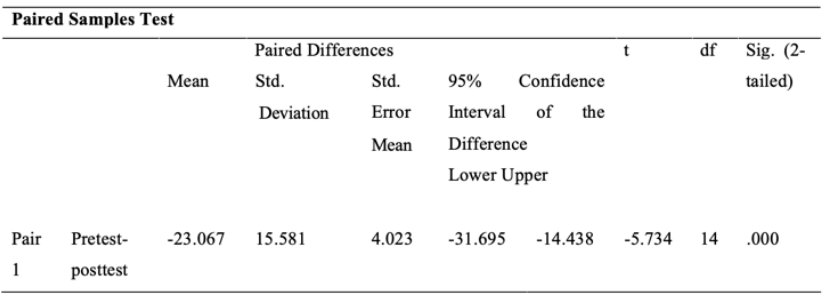

The table showed that the t-value for the pre-test and post-test differences in the quality of life of hypertensive patients before and after the administration of e-discharge planning is $-5,734$ with a probability (Sig.) of 0,000 . It can be drawn results $<0.05$ then there are differences in the quality 
of life of hypertension patients before and after the administration of e-discharge planning.

\section{DISCUSSION}

\section{A. Dimensions of physical health}

\section{1) Physical health}

In this domain, the self-assessment is focused on the limitation of daily activities, such as walking fast, the need for bathing and dressing, carrying goods, and several other things. This result supported by Munawwaroh (2017) that there is a relationship between physical activity and the quality of life of the elderly who suffer from hypertension. Good quality of life is characterized by an increase in physical activity undertaken. Doing physical activity can increase the life expectancy of patients to live longer, they can reduce blood pressure and reduce the risk of other degenerative diseases, one of which is stroke [8]. Quality of life is said to be good if the physical, psychological, and social health is good. ADL is included in physical health. The good physical condition will have a degree of independence in doing ADL and affect the quality of life [9].

\section{2) The role of physical health (role physical)}

The physical role is seen from the hindrance of daily activities due to problems in the physical health of the patient, such as the length of time required, the optimal achievement of the activities carried out, the limitations of doing activities and the difficulties in carrying out activities that require more physical effort. People with hypertension feel that they will undergo long-term treatment that is likely to be lifelong and a difficult healing process that causes stress in their lives, this creates negative feelings that will impact on the welfare of individuals [10].

Subjective well-being is the ability of individuals to evaluate life cognitively and affectively. Cognitively that is life satisfaction while effective that is positive affect such as feeling happy and excited and negative affect such as anger and anxiety [10]. People who suffer from hypertension have optimism in reducing feelings and negative views about the disease into positive feelings and views, giving rise to feelings of being able to deal with physical and psychological problems experienced to achieve a better quality of life than before. The better the adjustment to the illness, the better the quality of a person's life [11].

\section{3) Sick/Pain}

The body pain in question is how often hypertension sufferers feel pain in their body parts and whether the pain interferes with activity. In a study conducted by Zaenurrohmah (2017), the results show that as we get older, the physiological function will decrease due to the aging process, this causes susceptible non- communicable diseases to occur. Non-communicable diseases will reduce the body's immune system, causing a decrease in organ function that results in a person affected by diseases such as diabetes mellitus, hypertension, kidney failure, stroke, and others.

Hypertension is the most common cause of death that occurs in Indonesia, where an increase in blood pressure over a long period can result in damage to the kidneys which becomes kidney failure, damage to the brain that causes a stroke if not detected early and does not get appropriate treatment. Control measures in physical activity that are carried out are by measuring blood pressure regularly [12]. The results of the study of Suwadarna et al (2010) hypertension can affect the quality of life of the elderly. Quality of life is related to health, an individual's satisfaction or happiness throughout his life affects them or is influenced by health [13].

\section{4) General health}

Public health describes the state of a person's current level of health, and describes the current perceived health, whether it interferes with daily activities or not, public health can be affected by the aging process which is a physiological process experienced by every human which results in decreased physiological function and organ function so that it can affect public health and disrupt a person's quality of life [4].

\section{B. Dimension of Emotional/mental health}

\section{1) Vitality}

As we age, our health and vitality will decrease, especially in the elderly, this decrease is due to reduced physical activity and poor nutrition. Physical activities that can be done by the elderly include walking, climbing stairs, carrying goods, and others. The level of vitality is seen from the level of fatigue in doing so [14]. There is a relationship between physical activity and quality of life of hypertensive sufferers. Good quality of life is characterized by an increase in physical activity undertaken, to increase life expectancy and reduce blood pressure [8].

\section{2) Social function}

The living environment is one of the factors that affect a person's quality of life. An uncomfortable environment will make someone experience difficulty in terms of adjusting. Changes in roles in the family, socioeconomic, and social community are also things that can be difficult to adapt [15]. The importance of social relationships with hypertension sufferers because social relations provided by other people will have a positive impact on hypertension sufferers to improve their health. Social relations in patients with hypertension can be in the form of emotional relationships such as reminding patients to maintain blood pressure stability, reminding them to always take medicine, get love and care from people around [16].

\section{3) Emotional role (emotional role)}

Wachhyu et al (2019) found that emotional roles are very important to be obtained from families which can be in the form of affection, listening to complaints, and showing pleasant faces when talking, this is a form of attention given to someone, because if they don't get enough attention, then stress will arise and can reduce the quality of life [17]. The family is the main support for hypertensive patients in maintaining health, in the care and prevention of health in other family members. If good family knowledge, then the behavior will get better, and vice versa [18].

\section{4) Emotional problems (Mental Health)}

Mental health will not be easily disturbed by stressors (the cause of stress), people who have a healthy mentality means being able to refrain from pressures that come both from themselves and others. Circumstances where the individual is not physically affected by the disease but 
actually the individual is experiencing pain that originates from the heart or soul then the disease is called mental illness [19]. Stress or no coping when overcoming the problem occurs due to the hormone epinephrine or adrenaline released in the body, this can increase blood pressure through arterial contractions or vasoconstrictive conditions and increased heart rate. As stress continues, blood pressure remains high and results in hypertension (Putri, 2018). If stress occurs in a long period of time it will cause complications and the impact of complications is the low quality of life [20].

\section{CONCLUSION}

There are differences in the quality of life of hypertensive patients before and after the intervention of e- discharge planning. The implementation of e-discharge planning is carried out by patients by seeing and following information in the home care record that has been made, and the quality of life of hypertensive patients at PKU Muhammadiyah Gamping Hospital has improved.

Before you begin to format your paper, first write and save the content as a separate text file. Complete all content and organizational editing before formatting. Please note sections A-D below for more information on proofreading, spelling and grammar.

\section{REFERENCES}

[1] WHO | Raised Blood Pressure. Diambil 4 Juli 2019, Dari Who Website:

Https://Www.Who.Int/Gho/Ncd/Risk_Factors/Blood_Pressure_Preval ence_Text/En; 2019.

[2] Riskesdas. Hasil Utama Riskesdas 2018. Kementrian Kesehatan Republik Indonesia. $\quad$ Diambil Dari Http://Www.Depkes.Go.Id/Resources/Download/InfoTerkini/Materi_Rakorpop_2018/Hasil\%20riskesdas\%202018.Pdf; 2018.

[3] Khalifeh, Malak. Salameh, Pascale. Hajje, Amal, Al. Awada, Sanna. Rachidi, Samar. Dan Bawah, Wafa. Hypertension in the lebanese adults : impact on health related quality of life. Jurnal Publish. 2019. Hal 327.

[4] Sari, D. S., Arina, Y. M. D., \& Ermawati, T. Hubungan pengetahuan kesehatan gigi mulut dengan status kebersihan rongga mulut pada lansia. Ikesma, 2015; 11(1)

[5] Afiani, N., \& Daramatasia, W. Analisis determinan kualitas hidup pada pasien dengan hipertensi derajat II. Diambil 5 Juli 2019, Dari Fkm Unair Website: Https://Fkm.Unair.Ac.Id/Analisis- DeterminanKualitas-Hidup-Pada-Pasien-Dengan-Hipertensi-Derajat-Ii; 2019.
[6] Pertiwiwati, E., \& Rizany, I. Peran educator perawat dengan pelaksanaan discharge planning pada pasien di ruang tulip 1C Rsud Ulin Banjarmasin. Dunia Keperawatan, 2017; 4(2), 82. Https://Doi.Org/10.20527/Dk.V4i2.2509

[7] Okatiranti. Gambaran pengetahuan dan sikap perawat dalam pelaksanaan discharge planning pada pasien diabetes mellitus type II. Jurnal Ilmu Keperawatan, 2015a; 3(1), 7.

[8] Munawwaroh, A. M. Hubungan antara aktivitas fisik dengan kualitas hidup pada lansia penderita hipertensi di Kelurahan Joyosuran Kecamatan Pasar Kliwon Surakarta. Naskah Publikasi Universitas Muhammadiyah Surakarta, 2017; 17

[9] Prihati, P. A. Hubungan tingkat kemandirian activity daily living (adl) dengan kualitas hidup lansia Dikelurahan Karangasem Kecamatan Laweyan Surakarta. Naskah Publikasi Universitas Muhammadiyah Surakarta, 2017; 17.

[10] Kumala, O. D., Kusprayogi, Y., \& Nashori, F. Efektivitas pelatihan dzikir dalam meningkatkan ketenangan jiwa pada lansia penderita hipertensi. Psympathic: Jurnal Ilmiah Psikologi, 2017; 4(1), 55-66.

[11] Anbaransan, S. S. Gambaran kualitas hidup lansia dengan hipertensi di wilayah kerja puskesmas rendang pada periode 27 februari sampai 14 maret 2015. Intisari Sains Medis,4(1), 113-124

[12] Zaenurrohmah, D. H., \& Rachmayanti, R. D. Relationship between knowledge and hypertension history with blood pressure control in elderly. Jurnal Berkala Epidemiologi, 2017; 5 (2), 174. Https://Doi.Org/10.20473/Jbe.V5i22017.174-184

[13] Saftarani, F., \& Rabbaniyah, F. Hubungan senam lansia terhadap kualitas hidup lansia yang menderita hipertensi di Klinik HV UMMI Kedaton Bandar Lampung. JK Unila, 2016; 1(2)

[14] Witard, O. C., Mcglory, C., Hamilton, D. L., \& Phillips, S. M. Growing older with health and vitality: a nexus of physical activity, exercise and 125 nutrition. Biogerontology, 2016; 17, 529-546. Https://Doi.Org/10.1007/S10522- 016-9637-9

[15] Yuliati, A., \& Ririanty, M. Perbedaan kualitas hidup lansia yang tinggal di komunitas dengan di pelayanan sosial lanjut usia (the different of quality of life among the elderly who living at community and social services). Pustaka Kesehatan, 2014; 2(1), 87-94.

[16] Putri, M. S. Gambaran kualitas hidup pada aspek hubungan sosial penderita hipertensi di wilayah Puskesmas Pajang Surakarta. Naskah Publikasi Universitas Muhammadiyah Surakarta Arofiati, F. 2019. EDischarge Planning Dalam Home Care Record.

[17] Wachhyu, N., Indarwati, R., \& Misbahatul, E. Hubungan antara dukungan keluarga dan self care management lansia dengan hipertensi di posyandu lansia Kelurahan Manyar Sabrangan Surabaya. Indonesian Journal Of Community Health Nursing, 2019; 3(1).

[18] Efendi, H., \& Larasati, T. Dukungan keluarga dalam manjemen penyakit hipertensi. Majority, 2017; 6(1).

[19] Fatmasari, D., Widyana, R., \& Budiyani, K. Spiritual emotional freedom technique (seft) untuk menurunkan stres pada pasien hipertensi. Jurnal Psikologi, 2019; 15(1), 10-19

[20] Hamid, A., Agama dan kesehatan mental dalam perspektif psikologi agama. Jurnal Kesehatan Tadulako, Januari. 2017. 